2014, Vol. 2, No. 2

\title{
Capabilities for Innovation in a Globalizing World: from Nearby or at a Distance?
}

\author{
Martin Gjelsvik
}

A B S T R A C T

Objective: This paper addresses the question of how clustering affects firms' capabilities to innovate.

Research Design \& Methods: This paper uses a specifically tailored survey carried out in 2013 of the geographical distance and scope of collaboration for innovation of 2002 firms located in the four largest Norwegian city-regions with the rest of the country as a separate category.

Findings: We find that a majority of firms are located in regional clusters. However, the number of international relations increases the capacity to innovate. An international business environment stimulates the capability to innovate more than being part of a regional cluster.

Implications \& Recommendations: Firms that successfully develop global pipelines to knowledge sources in distant locations often sidestep the risk of lock-in, associated with relying solely on local sources of information (Malecki, 2010; Fitjar \& RodríguezPose, 2011).

Contribution \& Value Added: Our findings suggest that caution should be exercised when invoking the concept of regional clusters to explain or define regional competitiveness. The cluster model obviously assigns too much importance to the regional business context, and to local interaction and externalities. These findings suggest that policies to advance the capabilities to innovate in Norwegian firms and regions may need to be revised.

Article type: original research paper

Keywords: Innovation; globalization; clusters; Norway

JEL codes: $\quad$ O31, O32; Q55

Received: 7 February $2014 \quad$ Revised: 1 May $2014 \quad$ Accepted: 15 May 2014

The author acknowledges financial support from the Research Council of Norway.

\section{Suggested citation:}

Gjelsvik, M. (2014). Capabilities for Innovation in a Globalizing World: from Nearby or at a Distance?. Entrepreneurial Business and Economics Review, 2(2), 7-19. 


\section{INTRODUCTION}

In economic geography the traditional view has been that physical proximity within cityregions and being part of an industrial cluster are keys for the innovative capacity of firms. This view is echoed in the management literature which holds a strong belief in the concept of regional clusters. Clusters have been defined as "geographical concentrations of interconnected companies and institutions in a particular field" (Porter, 1998). According to Porter, being localized in a cluster improves competitiveness by reducing transaction costs and increasing the flow of information, allowing firms easier access to specialized suppliers and employees; and by increasing firms' capacity for innovation and productivity growth. However, in a globalizing world the superiority of local clusters should be questioned. In line with this, the literature on global pipelines has been stressing the importance of establishing communication channels to the outside world (Bathelt et al., 2004). This paper addresses the question of how clustering effect firms' capabilities to innovate.

OECD advocates local clusters, arguing that "clusters create an environment conducive to productivity gain, which are a factor of growth, and so form a structure that helps enterprises meet the challenges of international competition" (OECD, 2009). However, extensive overlaps of knowledge among partners may constrain the potential for innovation, especially in small and homogeneous regions (Fitjar \& Rodríguez-Pose, 2011). Moreover, local sources of knowledge may not be fully updated, and distance related disadvantages may be mitigated through temporary proximity such as conferences and exhibitions. In other words, the superiority of regional clusters may be questioned in a globalizing economy. From the reasoning above, we question whether empirical innovation studies have kept pace with the fast changing economy, in this case the globalization of knowledge, value chains and labor markets. Have the ways to organize innovation processes changed in line with the way the economy and society has evolved? How do regional, national and international flows of knowledge affect the capacity of firms to innovate? These are vital issues in the discussion of Norway's future beyond oil and for the rest of Europe's efforts to cut loose from the recession.

\section{LITERATURE REVIEW}

Economists, sociologists, economic geographers, management researchers and policy makers have all taken a renewed and increased interest in the study of clusters since the 1990s. Evidence is abundant both in books and articles (Porter, 1990, 1998; Krugman, 1991; Saxenian, 1994; Baptista \& Swann, 1998) and publications of international organizations (World Bank, 2000; OECD, 2009). In the literature the work of Marshall (1920) is recognized as the point of departure for the discussions on the impact of clusters. He argued that a concentration of small businesses of a similar character in particular localities ("industrial districts") generates external economies of scale. These economies are external to the firm but internal to the localization, and increase the efficiency of each individual firm. He further proposed that externalities could take several forms: economies of specialization arising from inter-firm division of labor in complementary activities; economies of labor supply arising from the local pool of 
specialized labor; and the promotion of innovation and innovation diffusions arising from the mutual knowledge and trust through frequent interchange among the actors in the area (Marshall, 1920; Rocha, 2004). Marshall linked his macro-analysis of growth to his micro analysis of increasing returns to firms due to the external economies created within the district.

Piore and Sabel (1984) advanced the term "flexible specialization" to argue that small innovative firms are an alternative to the mass production model and its dependence on large corporations. In other words, they associate their flexible specialization model to the vertically disintegrated smaller firm in industrial districts. Their contribution to the evolution of the cluster concept is that the industrial district is an important spatial manifestation of the flexible specialization model. The benefits of inter-firm collaboration and trust gives rise to the spatial agglomeration (Rocha, 2004).

About the same time another perspective emerged: the transaction cost view of clustering. The theory of transaction costs was originally advanced by Oliver $E$. Williamson $(1975,1985)$ to predict the relative merits of firms, markets and relational contracts. This perspective was introduced to studies of the industrial geography of Southern California and The Bay Area (Storper \& Scott, 1989). The argument is that uncertainty is mitigated by outsourcing activities leading to a vertical disintegration of production chains. However, this disintegration does not come without costs, as it leads to increased transaction costs among the specialized firms. To minimize these inter-firm transaction costs, firms cluster geographically (Scott, 1988; Storper, 1997).

In the two recent decades, two historical features may have extended the importance of the cluster perspective: the globalization processes, including the emergent economies; and radical and fast technological advances. At first glance, this extensive interest in cluster formation seems counter intuitive in the context of globalization which reduces transportation and communication costs. To solve the paradox, it is useful to distinguish between traditional and modern theories of trade. The influential traditional model of Heckscher-Ohlin (1991) builds on David Ricardo's theory of comparative advantage by predicting patterns of commerce and production based on the factor endowments of a trading region. The model essentially says that countries will export products that use their abundant and cheap factor(s) of production. The principle of comparative advantage states that countries, or regions, with dissimilar resource endowments will exchange dissimilar goods. In other words, head-on competition is limited. Later theories take as a vantage point that countries actually exchange very similar products (Storper et al., 2002) which are based on knowledge-intensive activities (Dunning, 1998). This is partly explained by consumer preferences for diversity. This development causes intensified competition which calls for innovation, quality and dynamic capabilities in firms. In other words, competitive advantage stems from the rate of learning and the capacity for innovation, rather than low cost.

Globalizing forces trigger the clustering of economic activity via the concentration of innovation, making regions a key source of advantage. In sum, this process relies on competitive advantage, external economies, increasing returns no scale and noneconomic factors, rather than comparative advantage, low cost and perfect competition (Rocha, 2004). In contrast to most treatments of competitiveness, which concentrate either on macroeconomic policies or on comparative advantages, Porter takes a different 
approach, arguing that the competitiveness of locations is primarily rooted in the nature of the business environment they offer firms (Martin \& Sunley, 2011).

Michael Porter has developed these perspectives on competitiveness further. He proposes a framework to analyze firm productivity and innovation capability in which location is a main source of competitive advantage within the context of a globalizing economy. Porter defines clusters as "a geographically proximate group of interconnected companies and associated institutions in a particular field, linked by commonalities and complementarities" (Porter, 1997, p. 199). According to Porter, being localized in a cluster improves competitiveness by reducing transaction costs and increasing the flow of information, allowing firms easier access to specialized suppliers and employees; and by increasing firms' capacity for innovation and productivity growth. Porter argues that productivity and innovativeness are outcomes strongly influenced by the quality of the business environment, which in turn is developed through the interaction and dynamism between four factors: factor conditions; demand conditions, related and supporting industries and institutions; and the context for firm strategy and rivalry. These four primary facets constitute his so-called diamond model in which they are regarded as a spatial manifestation of the diamond's interactions and are held to affect competition in three broad way: "(...) first by increasing the productivity of constituent firms or industries, second by increasing their capacity for innovation (...) and third by stimulating new business formation that supports innovation and expands the cluster" (Porter, 1998, p. 213). This dynamic interaction leads to constant improvement and upgrading, which are the main mechanisms why competitive advantage is sustained over time.

Porter's approach provided three critical innovations (Ketels, 2011). First, he stressed the benefits of the dynamic interactions between the different elements in affecting the value creation potential of a company through productivity gains and innovations. Access to better skilled employees through a local labor market or university becomes an asset when market conditions create an incentive for firms to use these capabilities. Second, he introduced demand conditions as a critical influence on the value generation capabilities of firms within a location. According to Porter, a demanding market pushes firms to develop new and better products and services. Third, he acknowledges the role of related and supporting industries and institutions that contribute to the innovative capability of a firm by offering easy access to specialized inputs.

\section{MATERIAL AND METHODS}

In order to discuss the role of regional clusters, a survey was conducted in the spring/summer of 2013 of firms located in the four largest city regions of Norway. Data collection was administered by a professional firm (Ipsos MMI), and took the form of telephone interviews with the chief executives of the firms. The respondents were asked to take part in a subsequent web-survey.

The top managers were chosen for several reasons. As reported below, most Norwegian firms are small; the median in our sample has 23 employees. This gives us reason to believe that the chief executive has the best overview of the issues and questions at hand. Furthermore, Porter's work on clusters has been unique in capturing the imagination of business managers (Ketels, 2011). Their interest is partly driven by the 
fact that Porter connects his findings on clusters and competitiveness with key strategic issues that executives face. When contemplating their strategies on innovation capacity and responsiveness to globalizations, executives often invoke the concept and drivers of clusters. Globalization has changed the relevance of location for competition by exposing companies, directly or through the rivals or support organizations they face, to a much broader set of different business environments (Ketels, 2011). Companies have responded by reorganizing their geographic footprint of their value chains (Baldwin, 2006). The cluster framework provides them with a tool to think about these choices and evaluate potential locations in relation to relevant clusters. Positioning the company in relation to the competition, customers, advanced suppliers, relevant skills and research institutions is a strategic issue on which the chief executive is influential. Consequently, his or her opinion on the whereabouts of these actors may determine the location of the firm. Hence, using the chief executive as respondent is highly beneficial.

Combined, the four regions make up about half of Norway's population. We added a "rest category" of firms located outside these urban agglomerations in order to differentiate between agglomeration effects and cluster effects. The Oslo region (the capital) is by far the largest with its 1.4 million inhabitants, while Bergen, Trondheim and Stavanger are in the range between 300 000-400 000. The survey was based on a questionnaire incorporating questions from the Community Innovation Surveys (CIS), and further expanded by including questions on the location of partners (inside or outside the region) and whether or not the firm is part of a regional cluster. Firms with more than ten or more employees were randomly sampled from the Norwegian Register of Business Enterprise, which by law lists all firms in Norway. A city region comprises municipalities where ten present or more of the population commutes into one of the four cities. The data set includes 2002 responses.

Norway is an interesting case in the discussion of the geography of partners and clusters. Innovation has become an increasingly important driver of competition, especially in a high cost and high income country such as Norway. For a small and open country, the cluster framework provides a natural context in which to think about how to engage with open systems of innovations (Chesbrough, 2003).

Norwegian firms tend to pursue collaborative innovation strategies, investing less in intramural $R \& D$ and interacting more with external partners than firms in most other European countries (Fagerberg et al., 2009). A recent trend has been to pursue regional innovation policies, including the establishment of several instruments aimed at promoting regional growth through regional clusters (Hanssen et al., 2011). In addition, local governments in many regions have established joint development agencies to promote innovation and growth within the city-regions (Farsund \& Leknes, 2010). These agencies have prioritized cluster-based policies to foster innovation and competitiveness.

All the four city regions have one or more universities that are expected to contribute to regional development in their respective regions through research and education as well as direct collaboration with businesses. Each region also hosts one or more research institutions that conduct applied research, often on contracts for private companies. These institutions fill an important function in the Norwegian innovation system both in their own right and as a bridge between industries and universities (Hatakenaka et al., 2009). 
In addition to these policy initiatives from both central and local governments, Norway has a trust-based business culture, an efficient basis for the transfer of tacit knowledge, a vital asset for regional clusters. On the other hand, Norway is a small country with small regions and an open economy, which caters for building firms' innovative capacity from external interaction.

Table 1 offers the descriptive data for the firms in the sample, including industrial sector, ownership, size, education level and location.

Table 1. Descriptive data on the firms included in the sample

\begin{tabular}{|l|r|r|}
\hline Sector & \multicolumn{1}{|c|}{ Number of firms } & \% of sample \\
\hline Mining/quarrying & 32 & 1.6 \\
\hline Manufacturing & 339 & 17.4 \\
\hline Elec./gas \& water supply & 56 & 2.9 \\
\hline Construction & 341 & 17.5 \\
\hline Wholesale/retail trade & 402 & 20.6 \\
\hline Transport and storage & 115 & 5.9 \\
\hline Food service and accommodation & 153 & 7.8 \\
\hline Information and communication & 122 & 6.3 \\
\hline Financial services & 80 & 4.1 \\
\hline Other services & 312 & 16.0 \\
\hline
\end{tabular}

\begin{tabular}{|l|r|r|}
\hline Dependence (capital group) & Number of firms & \% of sample \\
\hline Parent & 59 & 1.6 \\
\hline Subsidiary & 352 & 17.6 \\
\hline Independent & 1591 & 79.5 \\
\hline
\end{tabular}

\begin{tabular}{|l|r|r|}
\hline Ownership & Number of firms & \% of sample \\
\hline Norwegian & 1666 & 83.2 \\
\hline Partly foreign & 71 & 3.5 \\
\hline Fully foreign & 265 & 13.2 \\
\hline
\end{tabular}

\begin{tabular}{|l|r|r|}
\hline City region & Number of firms & \% of sample \\
\hline Oslo & 501 & 25.0 \\
\hline Bergen & 308 & 15.4 \\
\hline Trondheim & 234 & 11.7 \\
\hline Stavanger & 351 & 17.5 \\
\hline Rest of Norway & 608 & 30.4 \\
\hline
\end{tabular}

\begin{tabular}{|c|c|c|c|}
\hline Variables & Mean & Median & Standard deviation \\
\hline Number of employees & 71.8 & 23 & 333.5 \\
\hline$\%$ university educated & 28.9 & 15 & 30.2 \\
\hline \% R\&D expenditure & 3.4 & 1 & 8.5 \\
\hline
\end{tabular}

Source: own study $(n=2013)$.

In accordance with the well-established CIS questionnaire on capturing the innovative capacity of firms, respondents were asked whether their firms had introduced any new and/or significantly improved products during the last three years. They were also asked if these products were new to the market, in which case they are classified as radical product innovations; or new to the firm. The latter is usually regarded as more incremental. Similarly the measure of innovation process was based on a question about 
whether the firm had introduced any new and/or significantly improved methods or processes for production or delivery of products during the last three years. If these new processes were new to the industry, they were classified as radical process innovations. Table 2 presents the share of firms surveyed which reported innovation within the respective categories.

The table shows some differences between the city regions. The capital Oslo and the "oil capital" Stavanger host the most innovative firms, with Bergen as a close third. Firms residing outside the four urban agglomerations tend to innovate somewhat less than firms in the city region.

Table 2. The share of firms having introduced innovations (in \%)

\begin{tabular}{|l|r|r|r|r|r|}
\hline \multirow{2}{*}{ Regions } & \multicolumn{2}{|c|}{ Product Innovations } & \multicolumn{1}{c|}{ Process Innovation } & \multicolumn{2}{c|}{$\begin{array}{c}\text { Number } \\
\text { of firms }\end{array}$} \\
\cline { 2 - 5 } & \multicolumn{1}{c|}{ Total } & \multicolumn{1}{c|}{ Radical } & \multicolumn{1}{c|}{ Total } & \multicolumn{1}{c|}{ Radical } & 501 \\
\hline Oslo & 56.5 & 33.3 & 41.9 & 15.4 & 308 \\
\hline Bergen & 53.6 & 26.6 & 45.5 & 16.9 & 351 \\
\hline Stavanger & 56.7 & 33.3 & 46.2 & 16.5 & 234 \\
\hline Trondheim & 46.2 & 28.6 & 47.0 & 17.9 & 608 \\
\hline Rest of Norway & 47.5 & 21.7 & 41.0 & 12.2 & 2002 \\
\hline Total & 52.2 & 28.2 & 43.5 & 15.1 & \\
\hline
\end{tabular}

Source: own study $(n=2013)$.

The concept of clusters is operationalized and measured based on Porter's socalled diamond model (Porter, 1990). In this model Porter identifies four sets of determinants of national or regional advantage: (a) factor conditions, (b) demand conditions, (c) relating and supporting industries and institutions, and (d) firm strategy, structure and rivalry. Factor conditions refer to the availability of resources and skills necessary for competitive advantage. The quality and the relevance to the firm of the regional labor market are vital in this respect. Related and supporting industries and institutions concern the presence in the region of suppliers that are internationally competitive and institutions such as financial institutions, universities and research institutions. These may aid firms in their innovative efforts by helping firms perceive new methods and opportunities. In the case where the most advanced and demanding customers are located in the region, the firms meet a pressure to improve and innovate, especially when combined with a vigorous domestic rivalry.

Table 3. The extent of regional clusters - the regional share of six factors (in \%)

\begin{tabular}{|l|r|r|r|r|r|}
\hline \multicolumn{1}{|c|}{ Variables } & \multicolumn{1}{c|}{ Oslo } & \multicolumn{1}{c|}{ Bergen } & \multicolumn{1}{c|}{ Stavanger } & Trondheim & \multicolumn{1}{c|}{$\begin{array}{c}\text { Rest of } \\
\text { Norway }\end{array}$} \\
\hline Demanding customers & 57.9 & 64.9 & 74.4 & 73.5 & 60.0 \\
\hline Advanced suppliers & 35.9 & 49.1 & 47.4 & 51.1 & 31.0 \\
\hline Toughest competitors & 66.6 & 59.7 & 58.8 & 63.3 & 53.6 \\
\hline Most qualified employees & 76.8 & 70.9 & 71.4 & 79.6 & 79.0 \\
\hline Most relevant research institutions & 48.9 & 38.2 & 42.9 & 73.5 & 18.6 \\
\hline Access to capital & 65.9 & 66.7 & 66.7 & 67.4 & 67.2 \\
\hline Average & 58.7 & 58.3 & 60.3 & 68.1 & 51.6 \\
\hline
\end{tabular}

Source: own study $(n=2013)$. 
The issue is whether or not the focal firm is located within a regional cluster. In accordance with Porter's theory, we asked the managers where (region, nation, international) the following actors are located: the most demanding customers, the most advanced suppliers, the toughest competitors, the most qualified employees, the most relevant research institutions, and where they access capital. In other words, six items are used to capture the existence of clusters as experienced by the managers of the firms. Table 3 shows to which extent (the share of) these six factors are located regionally.

The table indicates that a share between $58 \%$ and $68 \%$ of the firms based in the four respective regions report positively being part of a regional cluster, measured by the six items derived from Porter's diamond model. Qualified employees are most often found locally, advanced suppliers to a lesser extent. Not surprisingly, firms outside the urban agglomerations report to a lesser extent the existence of a local cluster. There are only minor differences between the city regions, with the exception of Trondheim. Trondheim hosts a polytechnic university and the largest research institution in Norway; hence the firms located there benefit both from local research and qualified employees.

\section{RESULTS AND DISCUSSION}

Having established the prevalence of regional clusters, we next move to the main concern of this paper: do regional clusters promote innovation more efficiently in firms? We approach the issue by presenting some descriptive statistics first. The table 4 shows the share of firms having introduced new or significantly improved products and where the cluster factors are located.

Table 4. The effect of clusters on product innovation: share of firms having introduced new or significantly improved products (in \%)

\begin{tabular}{|l|r|r|r|}
\hline \multicolumn{1}{|c|}{ Variables } & \multicolumn{1}{c|}{ Regional } & \multicolumn{1}{c|}{ National } & \multicolumn{1}{c|}{ International } \\
\hline Demanding customers & 55.4 & 65.7 & 73.0 \\
\hline Advanced suppliers & 46.1 & 62.2 & 77.8 \\
\hline Toughest competitors & 51.6 & 69.0 & 80.0 \\
\hline Most qualified employees & 56.9 & 75.0 & 55.9 \\
\hline Most relevant research institutions & 52.8 & 63.8 & 75.5 \\
\hline Access to capital & 55.5 & 64.9 & 75.9 \\
\hline Average (un-weighted) & 53.1 & 66.8 & 73.0 \\
\hline
\end{tabular}

Source: own study $(n=2013)$.

The results indicate that being located in a regional cluster does not enhance the innovation capabilities of firms. On the contrary, firms facing their most demanding customers, the most advanced suppliers and toughest competitors, are international; seem to have a greater innovation capacity. Related support institutions for research and financial capital also grant improved innovation capacity when located internationally. On average, $53.1 \%$ of firms belonging to a regional cluster have developed new products in the past three years, as compared to $73 \%$ for firms relating to an international business environment.

Table 4 shows the effect on innovation of each of the six items in the cluster index. The strength of a cluster is argued to be the dynamic interaction between the elements. 
Hence, we have grouped the elements together. A firm is located in a regional cluster if all or most items related to a particular firm are located regionally. If none or very few elements are located regionally, the firm does not belong to a regional cluster. A firm belongs to a regional cluster if 4-6 elements are reported to be located regionally (Table 4). Firms reporting that $0-2$ elements are located in the region do not belong to a regional cluster. This group is called a non-regional cluster below, as the different partners or competitors are located outside the region, either in Norway or the rest of the world. The numbers show the share of companies having introduced innovations.

Table 5. The effect of regional clusters on innovation: the share of companies having introduced innovations (in \%)

\begin{tabular}{|l|r|r|r|}
\hline \multicolumn{1}{|c|}{ Variables } & Non-regional cluster & Regional cluster & \multicolumn{1}{c|}{ Average } \\
\hline New or significantly improved products & 70.2 & 49.1 & 59.7 \\
\hline New to market product innovation & 46.6 & 22.2 & 32.6 \\
\hline New or significantly improved processes & 46.6 & 44.4 & 47.8 \\
\hline New to market process innovation & 17.6 & 14.8 & 16.9 \\
\hline
\end{tabular}

Source: own study $(n=2013)$.

For product or service innovations, being located in a regional cluster is less efficient than being part of a national or international business environment. About half of the firms belonging to a regional cluster have introduced new products and services, compared to $70 \%$ of firms in a non-regional business environment. The relative difference is even more profound for radical product or service innovations, where the capacity to launch new products is twice as large as in regional clusters. However, for process innovations of both the incremental and radical kind the difference is almost negligible. The category non-regional cluster includes both the national and international business environment.

Are the differences we find really explained by the location of the firms and their association with either regional clusters or an international business environments? In a multivariate analysis we have controlled for some relevant other explanations such as the size of the firm, its ownership; in particular whether or not the ownership is foreign, the amount of R\&D expenditure, industrial sector and the manager's education level. In the analysis, firms' location in a regional cluster is used as a base line.

Table 6: The effect of clusters on product innovation: a multivariate analysis

\begin{tabular}{|l|c|c|}
\hline \multicolumn{1}{|c|}{ Variables } & $\begin{array}{c}\text { New or significantly } \\
\text { improved products }\end{array}$ & $\begin{array}{c}\text { Products new to the } \\
\text { market }\end{array}$ \\
\hline Scope & \multicolumn{2}{|c|}{0.09} \\
\hline National cluster & $0.23^{* * *}$ & $0.35^{* * *}$ \\
\hline International cluster & 0.11 & 0.20 \\
\hline Controls ${ }^{\text {a }}$ & \multicolumn{3}{|c|}{0.16} \\
\hline Size (log employees) & $0.35^{* * *}$ & 0.29 \\
\hline Manager's education level & 0.50 & $0.56^{* * *}$ \\
\hline Foreign ownership & $0.48^{* * *}$ & \\
\hline R\&D expenditure & & \\
\hline
\end{tabular}

$* * * p<0.01$

${ }^{\text {a }}$ Controls also include industrial sectors.

Source: own study $(n=2013)$. 
Being located in a national cluster or an international business environment enhances the capacity to innovate significantly; even controlled for other relevant factors. An international business environment is most beneficial for more radical innovations. These innovations typically build on original ideas and require more and more varied knowledge. This variety is more prevalent when relating to an international industry business climate. For products and services where the element of newness is less, more incremental innovations, being part of a national cluster is preferable. Given that regional clusters are least efficient, these results seem logical. For incremental innovations it suffices to broaden the scope from the regional to the national level. For more radical innovations, where the requirements for originality are more prevalent, the innovative firm has to widen their lenses to the international business environment.

\section{CONCLUSIONS}

The underlying assumption of the cluster model is that regional clustering enhances innovation. Studies of clusters have tended to be case studies of innovative regional clusters, typically successful ones, such as Silicon Valley and Route 128 in Boston (Saxenian, 1994). Our first contribution is the attempt to compare the performance of firms located inside clusters with those located outside clusters. Few studies have done that before (Martin \& Sunley, 2011). Malmberg and Maskell (2002) sum it up: "Whereas economic geographers and others have devoted considerable efforts in documenting the existence of spatial clustering, not many attempts have been made in terms of showing differences in firm performance between those located inside and outside localized clusters" (p. 435). This study has measured performance as the degree of innovation. The results resemble a study from Sweden, in which Erikson and Lindgren (2009) report that localized concentrations of similar and related firms do not explain any substantial part of variations in firm competitiveness.

In the Norwegian context, it is as though the logic of the argument in favor of cluster benefits has been so self-evident that its empirical interrogation has been unnecessary. Recently, however, research has surfaced indicating that the extension to international collaboration for innovation is more advantageous than regional partnerships (Fitjar \& Rodríguez-Pose, 2011). They did not study clusters explicitly, however. Our second contribution is thus the explicit measurement of clusters, not only partnerships.

Thirdly, most prior studies have been limited to certain sectors, unable to ascertain the generalizability of their conclusions. Other studies have used patents as a measure of innovation, whereas the present study capture a much broader array of innovations. Using a survey yields greater opportunities than case studies to generalize the findings. Clusters have been measured in many ways (Rocha, 2004). In this paper we have made use of Porter's original and highly wiedespread definition of the concept, his so-called diamond model.

There are several reasons that the benefits of regional clusters have been exaggerated. Innovations are made of novel combinations (Schumpeter, 1934), capabilities, skills and resources (Fagerberg, 2005). It logically follows that the greater the variety of these inputs, the greater the scope for them to be combined in new ways, producing more advanced and sophisticated solutions. This study indicates that an 
international environment, not a regional cluster, is more beneficial not only for product innovations in general, but in particular those products and services new to the market. Historically, innovation is often the result of synthesizing or bridging ideas and knowledge from different domains (Hargadon, 2003). Similarly, Granovetter (1992) concludes that "the actor whose network reaches into the largest number of relevant institutional realms have an enormous advantage".

Moreover, in his seminal article, Granovetter (1973) theorized that weak ties, characterized by distant and more infrequent interaction, tended to supply novel information, whereas strong ties, with close and frequent interaction, may yield information that is already known. Excessive embeddedness can reduce the adaptive capacity of firms (Uzzi, 1996). In regional clusters firms may search for solutions too narrowly, what Levinthal and March called myopic learning (1993). Economists claim that clusters can suffer from adverse location selection as innovative firms try to avoid unwanted spillovers and other outward leakages. Firms that possess superior technologies, human capital, and suppliers have an incentive to locate away from other firms so that their knowledge advantages and awareness of opportinties do not leak out to neighboring firms (Shaver \& Flyer, 2000).

Table 6 demonstrates the strong influence of R\&D on firms' innovation capacity. It has been argued that clustering per se has a negative impact on firms' propensity to invest in R\&D. Firms in regional clusters with high technological capabilities are more likely to suffer from detrimental knowledge spillovers, reducing their incentive to invest in R\&D. In addition, clustered firms that are exclusively reliant on local networks may well be more likely to suffer from technological convergence and lock-in (Martin \& Sunley, 2011).

Our findings suggest that caution should be exercised when invoking the concept of regional clusters to explain or define regional competitiveness. The cluster model obviously assigns too much importance to the regionl business context, and to local interaction and externalities. These findings suggest that policies to advance the capabilities to innovate in Norwegian firms and regions may need to be revised.

\section{REFERENCES}

Baldwin, R. (2006). Globalization: The great unbundling(s). Prepared for the Finnsish EU Presidency. Helsinki: Prime Minister's Office.

Baptista, R., \& Swann P. (1998). Do firms in clusters innovate more?. Research Policy, 27, 525-540.

Chesbrough, H. (2003). Open Innovation: The New imperative for Creating and Profiting from Technology. Boston, MA: Harvard Business School Press.

Dunning, J.H. (1998). Regions, Globalization and the Knowledge Economy. Oxford: Oxford University Press.

Eriksson, R., \& Lindgren U. (2009). Localized mobility clusters: Impacts of labour market externalities on firm performance. Journal of Economic Geography, 9(1), 33-53.

Fagerberg, J. (2005). Innovation: A guide to the literature. In J. Fagerberg, D. C. Mowery, and R. R. Nelson (Eds.), The Oxford Handbook of Innovation. Oxford: Oxford University Press.

Fagerberg, J. \& Mowery, D.C. et al. (2009). The evolution of Norway's national innovation system. Science and Public Policy, 36, 431-444. 
Farsund, A. A., \& Leknes, E. (2010). Norske byregioner: Utviklingstrekk og styringsutfordringer. Kristiansand: Høyskoleforlaget.

Fitjar, R. D., \& Rodríguez-Pose, A. (2011). When local interaction does not suffice: Sources of firm innovation in urban Norway. Environment and Planning A, 43(6), 1248-1267.

Granovetter, M. (1992). Economic Institutions as Social Constructions: a Framework for Analysis. Acta Sociologica, 35(1), 3-11.

Granovetter, M. S. (1973). The strength of weak ties. American Journal of Sociology, 78, 1360-1380.

Hanssen, G.S., Nergaard, E., Skaalholt, A., \& Pierre. J. (2011). Multi-level governance of regional economic development in Norwy ans Sweden: too much or too little top-down control?, Urban Research and Practice, 4, 38-57.

Hargadon, A. (2003). How Breaktroughs Happen. Boston, MA: Harvard Business School Press.

Hatakenaka, S., Westnes, P. et al. (2009). The regional dynamics of innovation: A comparative study of oil and gas industry development in Stavanger and Aberdeen. International Journal of Innovation and Regional Development.

Ketels, C. H. M. (2011). Clusters and Competitiveness: Ports's contribution. Competition, Competitive Advantage and Clusters: The Ideas of Michael Porter. Oxford: Oxford University Press.

Krugman, P. (1991). Trade and Geography. Cambridge, MA: MIT Press.

Levinthal, D. A., \& March, J.G. (1993). The myopia of learning. Strategic Management Journal, 14, 95-112.

Malmberg, A., \& Maskell, P. (2002). The elusive concept of localization economies: toward a knowledge-based theory of regional specialization. Environment and Planning A, 34, 429449.

Marshall, A. (1920). Principles of Economics. London: Macmillan.

Martin, R., \& Sunley, P. (2011). Regional competitiveness: clusters or dynamic comparative advantage. In: R. Huggins \& H. Izushi (Eds.), Competition, Competitive Advantage and Clusters. Oxford: Oxford University Press.

OECD (2009). Clusters, Innovation and Entrepreneurship. J. Potter \& G. Miranda (Eds.). Paris: OECD.

Onsager, K., \& Aslesen, H. et al. (2010). City Regions, Advantages and Innovation. Oslo: Norsk institutt for by- og regionforskning.

Piore, M.J., \& Sabel, C.F. (1984). The Second Industrial Divide: Possibilities for Prosperity. New York: Basic Books.

Porter, M.E. (1990). The Competitive Advantage of Nations. New York: Free Press.

Porter, M.E. (1998). On Competition. Cambridge, MA: Harvard Business Review Books.

Reve, T., \& Jakobsen, E.W. (2001). Et verdiskapende Norge. Oslo: Universitetsforlaget.

Rocha, H.O. (2004). Entrepreneurship and development: the role of clusters. Small Business Economics, 23, 363-400.

Saxenian, A. (1994). Regional Advantage: Culture and Cimpetition in Silicon Valley and Route 128. Cambridge, MA: Harvard University Press.

Schumpeter, J.A. (1934). The Theory of Economic Development. Cambridge, MA: Harvard University Press.

Scott, A. (1988). New Industrial Spaces: Flexible Production Organization and Regional Development in North America and Western Europe. London: Pion Press. 
Shaver, J.M., \& Flyer, F. (2000). Agglomeration economies, firm heterogeneity, and foreign direct investment in the United States. Strategic Management Journal, 21(2), 1175-1193.

Storper, M. (1997). The Regional World. New York, NY: Guilford.

Storper, M., \& Chen, Y.C. et al. (2002). Trade and the location of industries in the OECD and European Union. Journal of Economic Geography, 2(1), 73-107.

Storper, M., \& Scott, A.J. (1989). The Geographical Foundations and Social Regulation of Flexible Production Complexes. In: J. Wolch \& M. E. Dear (Eds.), The power of Geography: How territory Shapes Social Life. London - New York, NY: Routledge, pp. 25-43.

Uzzi, B. (1996). The Sources and consequences of embeddedness for the economic performance of organizations: The Network Effect. American Sociological Review, 61(4): 674-698.

Williamson, O.E. (1975). Markets and Hierarchies. New York, NY: Free Press.

Williamson, O.E. (1985). The Economic Institutions of Capitalism: Firms, Markets, Relational Contracting. New York, NY: The Free Press.

WorldBank (2000). Electronic Conference on Clusters.

\section{Author}

\section{Martin Gjelsvik}

$\mathrm{PhD}$ in economics ( $\mathrm{Dr}$ oecon). Research Manager at the International Research Institute of Stavanger IRISI (Norway). Professor II at Stavanger Innovation Center (Norway).

Correspondence to:

Prof. Martin Gjelsvik, PhD

International Research Institute of Stavanger IRIS

P.O. Box 8046, N-4068 Stavanger, Norway

phone (+47) 518750 52, fax (+47) +4751875200

Martin.Gjelsvik@iris.no 
